\title{
Handling Cases of Sexual Violence against Children in North Aceh Regency (Overview: Law Number 23 Year 2002 and Aceh Qanun Number 11 Year 2008 Concerning Children Protection)
}

\author{
Abdullah \\ Doctoral Student in UIN Medan and Lecturer in Shari'ah Faculty, IAIN Lhokseumawe, Indonesia \\ abdullahimumali@gmail.com
}

\section{Abstract}

The impact of sexual violence in northern Aceh has destroyed the rule of law, individual rights and social order, through writing it will describe and analyze efforts to handle cases of sexual violence against children in the northern Aceh district. This type of research includes normative juridical research in which qualitative information and research data are mostly in the form of texts and a number of case studies. The results showed that: sexual violence against children in the district of North Aceh, namely rape, sexual harassment, sodomy, incest, escaping underage girls, molestation and intimidation. Adult actors sometimes have blood relations, kinship, educational relationships and have intimate relationships. Forms of handling cases by social services under the control of P2TP2A service units in collaboration or in partnership with various parties / institutions starting with assistance in the community, psychological recovery of victims, bringing victims to the doctor for vise and then proceed to the police station, continued to assist until the legal process in court there is legal certainty then the next handling will be handled by the government through the North Aceh district social service by maintaining security, fulfillment of restitution rights for victims, but this hope has not been realized maximally because the North Aceh district government has not made a comprehensive program for rehabilitation of victims, generally victims handed over to the family and facilitated to be entrusted in the salafi boarding school (traditional).
Keywords

Handling; sexual assault; law and Qanun

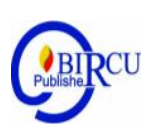

\section{Introduction}

Child abuse is all forms of physical, mental and sexual violence that result in disability or injury to the body and mind ${ }^{1}$. Whether carried out by individuals (individuals), groups of people (families), groups (institutions), or by the state, both have the potential or have resulted in neglect and abuse to the health, safety, development or honor of children. Henry Kempe mentions cases of neglect and abuse experienced by children with the term Battered Child Syndrome, namely: "Any situation caused by lack of care and protection of children by parents or other caregivers."Here, what are interpreted as acts of violence against children are not only serious injuries, but also minor injuries. ${ }^{2}$

\footnotetext{
${ }^{1}$ Qanun Aceh Nomor 11 Tahun 2008 Tentang Perlindungan Anak, (Pemerintahan Aceh, UNICEF 2009) p. 8

${ }^{2}$ Bagong Suyanto and Sri sanituti, Krisis \& Child Abuse, (Surabaya: Airlangga University, 2002),p. 114
} 
The experts classify acts of violence or violations against the rights of children of at least four forms, one of which is sexual violence, that is, any act in the form of sexual harassment, forced sexual relations improperly, forced sexual relations with others for commercial purposes and / or purposes specific purpose. ${ }^{3}$ Thus sexual violence is included in acts that insult, attack, use one's body and sexuality, forcibly with violence or threat of violence or other actions that cause a person unable to give consent in a free state that results in physical and psychological suffering. Including all types of sexual crimes such as incest, raping, including children in pornography, sexual slavery, giving inappropriate touches or showing sexual activity to children, using obscene words to children, and showing pornographic content to children.

According to Bagong Suyanto, included in the category of sexual violence ${ }^{4}$ are all acts that appear in the form of coercion or threatening to have sexual relations (sexuality intercourse), torture or act sadistic and leave someone - including those who are classified as children after sexuality. All behaviors that lead to acts of sexual abuse against children both at school, in the family and in the neighborhood around where children live are also included in the category of violence or violations of the rights of this type of children. Cases of child rape, molestation by teachers, others, even stepparents who are often exposed in reporting various mass media is a concrete example of this form of violence. ${ }^{5}$

The behavior of sexual violence above can occur in public areas (perpetrators who do not have kinship, blood or marriage) and personal (perpetrators have blood relations (father, brother, sister, and uncle), marriage (husband), kinship, intimate relations (girlfriend), or living with the victim), both male and female. Therefore, the writer tries to raise the issue, the core of his study rests on (1) Forms of sexual violence against children that occurred in North Aceh district (2) Handling cases of victims of sexual violence against children by social services under the P2TP2A North Aceh regency institution.

To answer the problems that arise in this paper, a theory foundation is needed to build or strengthen the truth of the problem being analyzed. First theory Legal protection as the main theory or theory framework (Grand theory). The subject of protection in the Child Protection Act is a child. The object of protection is the rights of every child. If the children's rights are violated, then the child is entitled to protection, subjects who are entitled to provide protection to the child include: the state, government, society, family and parents. Guardians and social institutions. ${ }^{6}$

The second continues on Medium Theory / middle theory (authority theory). According to DR. H Salim HS Theory of authority (authority of theory) is a theory that studies and analyzes the "power of government organs to exercise its authority both in the field of public law and private law" elements listed in the theory, including: the existence of power, the existence of organs the government and the nature of its legal relations. Government organs are government tools that have the task of running the wheels of government. Legal relations are relationships that cause legal consequences. The legal consequences are the emergence of

\footnotetext{
${ }^{3}$ Elucidation of article 28 letter b, Aceh Qanun Number 11 of 2008 concerning Child Protection.

${ }^{4}$ In general, violence comes from the word hard, whereas according to etymology violence means a matter of a hard nature or the actions of a person or group that causes death or causes pain to the body or causes injury to others, the Ministry of Education and culture, Kamus besar Bahasa Indonesia, (Jakarta: balai Pustaka, 1989 cet 2 p. 424.

${ }^{5}$ Ibid, Bagong, p 30.

${ }^{6}$ H. Salim HS dan Erlies Septiana Nurbani, Penerapan tiori hukum pada penelitian tesis dan disertasi ( Jakarta, PT Raja Grafindo, 2013), p 263
} 
rights and obligations. ${ }^{7}$ The final thesis is the supporting theory / applied theory (applicative theory), namely the sharia maqashid tiori, the sharia maqashid theory here is more focused on analyzing fiqh implementation in the context of state power and values in the form of human benefit in each taklif revealed by God.

\section{Research of Literature}

\subsection{The Phenomenon of Sexual Violence}

According to National Commission of Women annual records (annual record) from 2002 to 2012 victims of sexual violence were dominated by women, it is known that at least 35 Indonesian women are victims of sexual violence every day. This means that every 2 hours there are 3 Indonesian women who are victims of sexual violence. ${ }^{8}$ Whereas in 2016 the Ministry of Women's Empowerment and Child Protection recorded 8.5 percent of 87 million or as many as 900 thousand children in Indonesia were suspected to have been victims of sexual crimes of 'predators' of children. Based on the results of a 2013 survey, boys were twice as likely to experience sexual violence as girls because in addition to predatory goals, boys were stronger and more resilient; this was revealed by Deputy of Child Protection in the Ministry of PP and PA Pribudiarta Nur Sitepu. ${ }^{9}$

In terms of the number of National Commission of Women records that in 2014 there were 4,475 cases of sexual violence against women and children, in 2015 there were 6,499 cases, in 2016 there were 5,785 cases and in 2017 there were 5,649 cases. As for the province of Aceh Since 2015-2017, the Integrated Service Center for the Empowerment of Women and Children (P2TP2A) Rumoh Putroe Aceh noted, the number of violence against women and children per year has increased sharply. In 2015 there were 939 cases, in 2016 there were 1,648 cases, and in 2017 there were 1,791 cases. $^{10}$

Based on data from the Integrated Service Center for Empowerment of Women and Children (P2TP2A) in Aceh there are seven districts / cities with the highest handling of cases in 2016-2018 namely cases of violence experienced by women and children. Pidie regency recorded 7\%, Bener meriah district 9\%, Aceh Tengah 9\%, Bireun regency 12\%, Aceh Besar 13\%, Aceh Utara 25\% and the city of Banda Aceh $25 \% .{ }^{11}$ From the data, North Aceh regency is one of the districts that has the highest number of violence against women and children because North Aceh Regency besides its area is wider than other regency areas of the city as well as the largest population after Banda Aceh.

The recapitulation results of the Office of Women's Empowerment and Child Protection KP3A (North Aceh district, 2013 cases of rape children (28 cases), 2014 (22 cases), 2015 (27 cases), 2016 (31 cases), 2017 (39 cases) and in the year 2018 (24 cases), for 2013 sexual harassment cases ( 2 cases), 2014 (4 cases), 2015 (5 cases), 2016 ( 9 cases), 2017 (13 cases), and 2018 (11 cases), while for cases sodomy in 2013 (8 cases), 2014 (2 cases), 2015 ( 4 cases), 2016 and 2017 did not exist, in 2018 there were ( 1 case) $:^{12}$

Given the above phenomena and the child as an immature individual physically, mentally and socially, as a result of inattention that children must get protection from adults.

\footnotetext{
${ }^{7}$ Ibid. p. 186

${ }^{8}$ Document of Komnas Perempuan year 2016

9 Tajuk Rencana, Harian Waspada, 3 October 2016, p. B6

${ }^{10}$ https://kumparan.com, Accessed August 10, 2019

${ }^{11}$ Pusat Pelayanan Terpadu Pemberdayaan Perempuan dan Anak (P2TP2A) Aceh

${ }^{12}$ Sumber kantor BP3A kabupaten Aceh Utara, tanggal 28 maret 2016
} 
The form of handling ${ }^{13}$ so that the existence of the child is protected from various forms of sexual violence threats in the form of anticipation / prevention (prevention) or nurture the victim and punish the perpetrators (repressive) after committing acts of violence. If these actions are not taken early in the child's rights in the form of non-discrimination, the best interests of the child, the fulfillment of the right to grow and develop, respect and protect their honor will be ignored

\subsection{The Presence of Children in Islam}

According to Islamic teachings children are a trust from Allah and cannot be considered as property that can be treated at will by anyone. Children in Islam are socialized as creatures of God who are wise and have a noble position, whose existence is through the process of creation which has the dimension of the will of Allah ${ }^{14}$. Rationally, a child is formed from supernatural elements that are transcendental from the process of ratification of science (science) with scientific elements taken from the material values of the universe and spiritual values taken from the process of belief (Islamic monotheism). ${ }^{15}$ Explanation of the status of children in Islam is affirmed in the Qur'an: (QS, al-Isra 'verse: 70) which means: "And verily we have glorified the children of Adam, We transport them on land and in the sea, we give they are good fortune and we provide them with a perfect advantage over most of the creatures that we have created"

Islam's concern for children has actually started from the process of creating babies from mudghah (sperm), then 'alaqah (blood clots) and to the mudghah (collection of flesh that has been blown by spirits). The last condition of the fetus is that there are legal provisions that bind it, which must be protected by safety.

No one would deny that abortion (abortion) at that time was included as an act of murder of one life that has penetrated the way of life. ${ }^{16}$ When the fetus was born, Islam also calculated it, Imam Shafi'i argued that the release of a fetus that was in the form of a human being would be related to the law, and if the birth was not safe or dead (screaming or crying) he must be disregarded. Narrated from al-Mughirah bin Syu'bah that they were ordered to pay respect to the fetus who died. He said "Give names, bathe, kafani, and bury them. Verily with Islam Allah glorifies the old and the young." 17

In Aceh and West Sumatra, in the culture and structure of the Acehnese society, cultural values stem from Islamic values. Indigenous ngon hukom (religion), but the substance ngonsifeut, meaning that Aceh's traditional values are integrated with religious values. 6 This is reflected in one of the social institutions of the Acehnese community known as the gampong pageu. West Sumatra is also known as Adat Basandi Syara ', Syara' Basandi Kitabullah (ABS SBK), Syara 'mangato, Adat mamakai. This philosophy has confirmed the existence of Islam in social life in its community, and become an inseparable thing in their daily lives. These values apply in various institutions, such as surau, family institutions (rumah gadang) and other institution.(Abdullah, 2018)

\footnotetext{
${ }^{13}$ Penanganan bermakna Proses, cara, perbuatan menangani (mengerjakan atau menggarap sendiri), Suharso dan Retno Ningsih, Kamus Besar Bahasa Indonesia, edisi Lux (Semarang: Widya Karya, 2012), p.. 525

${ }^{14}$ Imam Jauhari, Advokasi Hak-hak Anak ditinjau dari hukum Islam dan peraturan perundang - undangan,

(Medan: Pustaka bangsa, 2008), p. 46

${ }^{15}$ bid.

${ }^{16}$ Ahmad al-mursi Husain jauhar, Maqashid Syari'ah, terj (Khikmawati kuais, (Jakarta: Sinar Grafika Offset, 2009), p.. 37

${ }^{17}$ Ahmad al-mursi..., Maqashid Syari'ah, p. 37
} 
In the concept of figh protection for children continues both in infancy and in adolescence where a child has received protection from mothers for breastfeeding both his own mother or another woman called by the term ridha'ah (breastfeeding), when the age of mumaiz gets protection for maintenance or the upbringing of his parents called hidhanah (tarbiyyah) even in the figh provisions "If a husband and wife divorce and be with a child who has not been mumaiz (do not understand his benefit), then the wife has more right to educate children until 7 (seven) years of age, then (after more than seven years) the child can choose which one they like. Wives who are entitled to care for children must fulfill seven conditions: al-aqlu (understanding, (independent) al-din (practicing religion), iffah (able to maintain self-respect), amanah (trustworthy person), iqamah (person who is trustworthy) settled in the country of the child he educated), khalwu min zaujin (unmarried woman). ${ }^{18}$

The obligation for parents (fathers / guardians) to protect the body from the threat of starvation is the cost of daily life termed nafaqah. As for nafaqah in fiqh, it is explained in a separate discussion, namely: "nafaqatu al-'umudain min wajibatun li al-walidaini wa almauludina"19 i.e. where parents (father / guardian) are obliged to bear the livelihood of the child if there are two deficiencies in the child that is poor and weak (still children) or poor and crazy. ${ }^{20}$

Protection in terms of the law for children also has a place in fiqh as well as legal protection for adults, it is not justified by anyone or any institution to carry out a lifethreatening act and honor, but not in a special discussion but scattered in several books such as the issue of this murder discussed in the book of ahkam jinayat, while the act of adultery and accusing adultery is discussed in the book of hudud (punishment). The chapters do not mention igtishab (depriving them of honor or rape) and explicit sexual harassment. But based on the approach of the qiyas (analogy) method of sexual violence, it can be likened to the existing original laws namely adultery, ikrah 'ala zina (coercion of someone to commit adultery), mufakhazhah (مفاخذة) sexual harassment (at-taharusy) which is not up to committing adultery, istimna '(fondling), liwat (homosexual) and musahaqah (lesbian).

All forms of the above actions are classified in the act of jarimah in Islamic criminal because in the act there are acts of violence, an action referred to as violence is basically because in the act of storing the meaning of persecution in Arabic called with dhalim. If the "violence" diction is attached to "sexual" so as to form the phrase "sexual violence", then what is meant by sexual violence are all actions that contain an "element of persecution" oriented towards sexual cases. Every act of persecution, the substance of the meaning of coercion (ikrah) is attached. For example rape case. Rape is an act of wrong doing (persecution). That injustice was caused by the element of coercion (ikrah) to have sexual relations with other people, causing physical injury, in the form of loss of honor. If you look at the existence of elements of ikrah and persecution, then in essence the case of sexual violence in the Shari'a also includes cases of sexual harassment. This is reflected in (QS AnNur verse 30).

The substance of the verse is the order to hold one's view, guard farji and guard the nakedness which is the entrance to sexual harassment. This is as reflected in the interpretation conveyed by Al-Thabary in the book of interpretation of Jami'u al-Bayân li Ayi al-Qurân which means: "Allah SWT reminds of His Prophet Muhammad SAW: (Say to the believers), By Allah and For your sake, O Muhammad, (holding his eyes), ie refraining from looking at

\footnotetext{
${ }^{18}$ Ibnu qasim al-ghazhi, Fathul Qarib al-Mujib, jilid 3, Semarang: Haramai, t.th. p. 197-198)

19 والجنون p. p. 46

${ }^{20}$ Ibid.
} 
something that invites eyes but is forbidden by Allah SWT from looking at him, (and keeping his eyes) from being shown to people who are not lawful for him to see, covering the limbs from their sight . (That is the cleanest for them)." 21

Thus shari'ah (qur'an / hadith) and fiqh do not mention concrete forms of sexual violence that are still generally not found concretely terms of sexual violence against children along with the application of punishment for the perpetrators, so that now among contemporary scholars can lead to two views different, namely acts of violence against children included in the category of jarimah $u d u d^{22}$ and or jarimah ta'zir ${ }^{23}$ However, the mujtahids have laid down the basic law against the perpetrators of adultery for example by stoning or binding 100 times. As for the crime of Jarimah Liwat, Mukhafadhah, Ikrah 'Alazina and Musahaqah and Istimna', the sanctions are different from the criminal acts of Jarimah Adultery.

The provisions for the protection of victims in the Islamic criminal law system (jinayat) are found in criminal cases of murder and ill-treatment by applying the diyat concept, this is mentioned in the Qur'an (Q: S, Albaqarah [2] paragraph 178), from paragraph it can be concluded that diyat is an asset that must be given by the perpetrators of the crime of murder or ill-treatment to the victim or the victim's family, even though the form of punishment (sanctions), diyat is a property given to the victim, not to the treasury. In this aspect diyat can be equated with compensation losses. More precisely diyat is mentioned as a mixture of punishment and compensation. Said to be a punishment because diyat is a form of sanctions against criminal acts (jarimah) that have been carried out by the perpetrators. Diyat also as compensation for diyat received by the victim in full. ${ }^{24}$

\section{Discussion}

\subsection{Forms of sexual violence against children in northern Aceh}

North Aceh Regency consists of 27 sub-districts, all sub-districts occurred acts of sexual violence, but all cases of sexual violence were not recorded as a whole in related institutions because there was an effort by some people to hide the case from the knowledge of the excuse because in order to protect the honor or good name of the victim from knowledge Public, below are some of the results of recapitulation of related institutions concerning victims of sexual violence against children.

Number of cases of sexual / district violence Within the district area of North Aceh ${ }^{25}$

\begin{tabular}{|l|l|c|c|c|}
\hline No & Sub-district & 2016 & 2017 & 2018 \\
\hline $\mathbf{1}$ & Sawang & 4 & 4 & 4 \\
\hline
\end{tabular}

\footnotetext{
${ }^{21}$ Ibn Jarir al-Thabary, Jâmi'u al-Bayân li Ayi al-Qur'ân, Beirut: Dar al-Ma'rifah, tt.: 353

${ }^{22}$ Crime that is threatened with punishment had, is the penalty that has been determined oleh nas (al-Qur'ānd an al-Hadīth), there are no two limits (the lowest and highest limits) and cannot be replaced by other penalties, because it is a rightof Allahlm. Jamal 'Ațiyah dan Wahbah al-Zuhailī, Tajdīd al-Fiqh al-Islāmī, (Bairūt: Dār alFikr dan Damascus: Dār al-Fikr, 2000) p.. 328

${ }^{23}$ Punishments not determined by naș relating to crimes that violate the rights of God and the rights of servants which serve to teach the perpetrators of crimes and prevent them from repeating similar crimes. 'Atiyyah Musțafā Musyarrafah, Al-Qaḍā fì al-Islām, (T.tp: Syirkah al-Syarq al-Awsāṭ, 1966), p. 149.

${ }^{24}$ Ahmad Hanafi, Asas-asas hukum pidana Islam (Jakarta Bulan bintang, 1993), p. 284

${ }^{25}$ Eliati marzuki, ketua P2TP2A kabupaten Aceh Utara, diambil pada tanggal 25 November 2019.
} 


\begin{tabular}{|l|l|c|c|c|}
\hline 2 & Dewantara & 2 & 5 & 2 \\
\hline 3 & Baktiya & 2 & 2 & 3 \\
\hline 4 & Lapang & 2 & 1 & 1 \\
\hline 5 & Simpang Kramat & 2 & 2 & 0 \\
\hline 6 & Nisam Antara & 0 & 2 & 1 \\
\hline 7 & Samudra & 1 & 2 & 1 \\
\hline 8 & Seunudon & 2 & 3 & 2 \\
\hline 9 & Muara Batu & 2 & 2 & 2 \\
\hline 10 & Pirak Timu & 1 & 0 & 0 \\
\hline 11 & Cot Girek & 2 & 1 & 1 \\
\hline 12 & Meurah Mulia & 1 & 1 & 1 \\
\hline 13 & Baktiya Barat & 1 & 1 & 2 \\
\hline 14 & Langkahan & 1 & 3 & 2 \\
\hline 15 & Tanah pasir & 3 & 2 & 3 \\
\hline 16 & Kuta Makmur & 2 & 2 & 1 \\
\hline 17 & Lhoksukon & 4 & 4 & 3 \\
\hline 18 & Tanah jambu Aye & 4 & 4 & 4 \\
\hline 19 & Nisam & 2 & 2 & 2 \\
\hline 20 & Nibong & 2 & 2 & 1 \\
\hline 21 & Tanah luas & 2 & 1 & 0 \\
\hline 22 & Syamtalira Bayu & 0 & 1 & - \\
\hline 23 & Banda Baro & 1 & 1 & 0 \\
\hline 24 & Syamtalira Aron & 0 & 2 & 2 \\
\hline 25 & Matang kuli & - & - & - \\
\hline 26 & Buloh blang Ara & - & - & - \\
\hline 27 & Geurudong Pase & - & - & - \\
\hline & Total cases & 42 cases & 50 cases & 38 cases \\
\hline & & & & \\
\hline
\end{tabular}

Based on the recapitulation results of the Office of Women Empowerment and Child Protection, KP3A (North Aceh district for the last three years (2013 - 2015) as shown in the following table ${ }^{26}$ :

\begin{tabular}{|l|c|c|c|}
\hline \multicolumn{1}{|c|}{ Case type } & 2013 & 2014 & 2015 \\
\hline Child rape & 28 & 22 & 27 \\
Sexual harassment & 2 & 4 & 5 \\
Domestic Violence & 43 & 33 & 34 \\
Rape & 7 & 7 & 5 \\
Daring & 5 & 2 & 5 \\
Traumatic & 29 & 10 & 50 \\
Sodomy & 8 & 2 & 4 \\
Child Murder & 1 & 1 & 3 \\
Child Incest & 2 & - & - \\
\hline Total & 512 & 81 & 143 \\
\hline
\end{tabular}

${ }^{26}$ Sumber kantor BP3A kabupaten Aceh Utara, tanggal 28 maret 2016 
Whereas in 2016 to 2018 as follows:

\begin{tabular}{|l|c|c|c|}
\hline \multicolumn{1}{|c|}{ Case type } & 2016 & 2017 & 2018 \\
\hline Child rape & 31 & 39 & 24 \\
Sexual harassment & 9 & 13 & 11 \\
Domestic Violence & 55 & 48 & 58 \\
Rape & 2 & 6 & 4 \\
Persecution & 7 & 4 & 5 \\
Traumatic & 4 & 12 & - \\
Sodomy & - & - & 1 \\
Child Murder & - & 4 & - \\
Child Incest & - & - & - \\
Dispose of the baby & - & 4 & - \\
\hline Total & 511 & 136 & 103 \\
\hline
\end{tabular}

The details of cases of sexual violence based on data from the Integrated Service Center for Empowerment of Women and Children (P2TP2A) North Aceh in January - August 2016 there were 34 cases:

Victims of sexual violence against children in North Aceh district January - August $2016 .^{27}$

\begin{tabular}{|c|l|l|l|l|l|}
\hline No & \multicolumn{1}{|c|}{ Initials } & $\begin{array}{l}\text { Relationship } \\
\text { with victims }\end{array}$ & Sub-District & \multicolumn{1}{|c|}{ Handling } & Information \\
\hline 1 & $\begin{array}{l}\text { Rz (16) } \\
\text { Junior High } \\
\text { school } \\
\text { student }\end{array}$ & Neighbors (28) & Nibong & $\begin{array}{l}\text {-Community } \\
\text {-Police } \\
\text {-P2TP2A } \\
\text { Assistance at } \\
\text { the police } \\
\text { station }\end{array}$ & $\begin{array}{l}\text { Attempted } \\
\text { rape }\end{array}$ \\
\hline 2 & $\begin{array}{l}\text { Sw bt Z } \\
(15)\end{array}$ & Foreigners & Baktya barat & $\begin{array}{l}\text { - Community } \\
\text {-Police } \\
\text {-Attorney }\end{array}$ & $\begin{array}{l}\text { Attempted } \\
\text { rape }\end{array}$ \\
\hline 3 & $\begin{array}{l}\text { Mu bt Ab } \\
(16)\end{array}$ & Boyfriends & Samudera & $\begin{array}{l}\text {-P2TP2A } \\
\text { Assistance in } \\
\text { the } \\
\text { community, } \\
\text { Polres and in } \\
\text { the court } \\
\text {-Stage trial in } \\
\text { court }\end{array}$ & $\begin{array}{l}\text {-disability } \\
\text {-raped in } \\
\text { turns with 5 } \\
\text { of the } \\
\text { perpetrators' } \\
\text { friends }\end{array}$ \\
\hline 4 & $\begin{array}{l}\text { Sal bt Md } \\
(16)\end{array}$ & $\begin{array}{l}\text { Foreigners } \\
(25)\end{array}$ & Buloh b.ara & $\begin{array}{l}\text {-P2TP2A } \\
\text { Assistance in } \\
\text { the }\end{array}$ & $\begin{array}{l}\text {-Disability } \\
\text {-The offender } \\
\text { was released } \\
\text { because there }\end{array}$ \\
\hline
\end{tabular}

${ }^{27}$ Dokumen P2TP2A Kabupaten Aceh Utara 5 November 2016 


\begin{tabular}{|c|c|c|c|c|c|}
\hline & & & & $\begin{array}{l}\text { community, } \\
\text { police station, } \\
\text { court and seek } \\
\text { witnesses } \\
\text {-The } \\
\text { prosecutor is in } \\
\text { the } \\
\text { investigation }\end{array}$ & $\begin{array}{l}\text { was not } \\
\text { enough } \\
\text { evidence }\end{array}$ \\
\hline 5 & $\begin{array}{l}\text { Db bt Sl, (8) } \\
\text { Elementary } \\
\text { school } \\
\text { students }\end{array}$ & Father & Langkahan & $\begin{array}{l}\text { - P2TP2A } \\
\text { Community } \\
\text { and police } \\
\text { assistance, } \\
\text { - Prosecutor: in } \\
\text { the proof } \\
\text { stage, because } \\
\text { there was not } \\
\text { enough } \\
\text { evidence then } \\
\text { the case was in } \\
\text { SP3 (stopped) }\end{array}$ & $\begin{array}{l}\text {-Rape } \\
\text {-Founded } \\
\text { repeatedly } \\
\text { recognition } \\
\text { of his } \\
\text { biological } \\
\text { mother. }\end{array}$ \\
\hline 6 & $\begin{array}{l}\text { Ra (11) } \\
\text { Elementary } \\
\text { school } \\
\text { students }\end{array}$ & Steps father & Langkahan & $\begin{array}{l}\text {-P2TP2A } \\
\text { Assistance in } \\
\text { the } \\
\text { community, } \\
\text { Polres. } \\
\text { - Attorney } \\
\text { legal } \\
\text { proceedings in } \\
\text { court } \\
\text {-Polres: arrest } \\
\text { the perpetrator } \\
\text {-Course: legal } \\
\text { proof process }\end{array}$ & -rape 2 times \\
\hline 7 & $\begin{array}{l}\text { Ms,(11) } \\
\text { Elementary } \\
\text { school } \\
\text { students }\end{array}$ & Uncle (28) & Seunudon & $\begin{array}{l}\text {-P2TP2A } \\
\text { Community } \\
\text { and Polres } \\
\text { assistance } \\
\text {-P2TP2A } \\
\text { facilitated } \\
\text { victims to see } \\
\text { doctor Nila for } \\
\text { medical needs. } \\
\text {-Court; Proof } \\
\text { process } \\
\text {-Polres; } \\
\text { temporary } \\
\text { detention }\end{array}$ & $\begin{array}{l}\text {-Rape twice } \\
\text {-the victim } \\
\text { was secured } \\
\text { at his } \\
\text { grandmother' } \\
\text { s house }\end{array}$ \\
\hline
\end{tabular}




\begin{tabular}{|c|c|c|c|c|c|}
\hline 8 & $\begin{array}{l}\mathrm{Nm} \text { bt } \mathrm{Nw}, \\
(16)\end{array}$ & Computer tutor & Lhoksukon & $\begin{array}{l}\text {-P2TP2A } \\
\text { Community } \\
\text { facilitation, } \\
\text { Polres, } \\
\text {-Polres: cannot } \\
\text { be continued } \\
\text { legally by } \\
\text { reason of lack } \\
\text { of evidence }\end{array}$ & Sexual abuse \\
\hline 9 & $\begin{array}{l}\text { Nei bt Sya, } \\
(9) \\
\text { Elementary } \\
\text { school } \\
\text { students }\end{array}$ & $\begin{array}{l}\text { Steps Father } \\
(38)\end{array}$ & Banda Baro & $\begin{array}{l}-\mathrm{P} 2 \mathrm{TP} 2 \mathrm{~A} \\
\text { Assistance in } \\
\text { the } \\
\text { community, } \\
\text { the police } \\
\text { station and in } \\
\text { the court }\end{array}$ & Rape \\
\hline 10 & $\begin{array}{l}\text { Nur bt Ib } \\
(12) \\
\text { Elementary } \\
\text { school } \\
\text { students }\end{array}$ & Neighbor & Tanah Luas & $\begin{array}{l}\text {-family } \\
\text {-Police } \\
\text {-Polres, due } \\
\text { process of law }\end{array}$ & $\begin{array}{l}\text { Rape, police } \\
\text { detainee }\end{array}$ \\
\hline 11 & $\begin{array}{l}\text { Pm, (17) } \\
\text { Senior } \\
\text { school } \\
\text { students }\end{array}$ & $\begin{array}{l}\text { Friend (Class } \\
\text { brother is still } \\
\text { a child) }\end{array}$ & Tanah pasir & $\begin{array}{l}\text {-family } \\
\text {-Police } \\
\text {-Polres: Legal } \\
\text { proceedings. } \\
\text {-Polres: } \\
\text { temporary } \\
\text { detention }\end{array}$ & $\begin{array}{l}\text {-Rape } \\
\text {-The victim } \\
\text { has been } \\
\text { secured at his } \\
\text { uncle's house } \\
\text { to Bireuen } \\
\text { district } \\
\text {-Police } \\
\text { detainees }\end{array}$ \\
\hline 12 & $\begin{array}{l}\text { Yo Binti } \\
\text { Sar, (17) } \\
\text { Senior } \\
\text { school } \\
\text { students }\end{array}$ & $\begin{array}{l}\text { Friend, grown } \\
\text { up }\end{array}$ & Langkahan & $\begin{array}{l}\text {-P2TP2A } \\
\text { Handling in } \\
\text { the } \\
\text { community, } \\
\text { police station }\end{array}$ & $\begin{array}{l}\text { Love each } \\
\text { other } \\
\text { pregnant } \\
\text { victims, the } \\
\text { perpetrators } \\
\text { fled to } \\
\text { Jakarta and } \\
\text { were } \\
\text { determined as } \\
\text { DPOs }\end{array}$ \\
\hline 13 & Fit & $\begin{array}{l}\text { Friends, still } \\
\text { children }\end{array}$ & Cot girek & $\begin{array}{l}\text {-something } \\
\text {-Polsek } \\
\text {-Customary } \\
\text { leaders, } \\
\text { customary law } \\
\text { processes end }\end{array}$ & $\begin{array}{l}\text { Sexual } \\
\text { harassment }\end{array}$ \\
\hline
\end{tabular}




\begin{tabular}{|c|c|c|c|c|c|}
\hline & & & & in peace & \\
\hline 14 & $\begin{array}{l}\text { Sz bt Aw, } \\
\text { (10) }\end{array}$ & $\begin{array}{l}\text { Foreign } \\
\text { offenders } 4 \\
\text { children age, } \\
11,9.8,7\end{array}$ & Merah mulia & $\begin{array}{l}\text {-P2TP2A } \\
\text { assistance in } \\
\text { the } \\
\text { community, } \\
\text { and at the } \\
\text { police station } \\
\text { Prosecutor, the } \\
\text { legal process at } \\
\text { the police } \\
\text { station }\end{array}$ & rape \\
\hline 15 & NA, (17) & Friends (22) & Pirak Timu & $\begin{array}{l}\text {-P2TP2A } \\
\text { assistance in } \\
\text { the community } \\
\text {-family, Legal } \\
\text { consultation } \\
\text { with P2TP2A } \\
\text { Police, } \\
\text { temporary } \\
\text { detention. } \\
\text {-Polres, } \\
\text { continued } \\
\text { legally }\end{array}$ & rape \\
\hline 16 & $\begin{array}{l}\text { Nila bt MY } \\
\text { (16) }\end{array}$ & Cousin (22) & Seunudon & $\begin{array}{l}\text { P2TP2A } \\
\text { assistance in } \\
\text { the community } \\
\text {-Family legal } \\
\text { consultation } \\
\text { with P2TP2A }\end{array}$ & $\begin{array}{l}\text {-Rape } \\
\text { - give birth }\end{array}$ \\
\hline 17 & Cut, (16) & $\begin{array}{l}\text { Uncle, cousin } \\
\text { and neighbor } \\
\text { are } 10 \\
\text { thousand } \\
\text { people }\end{array}$ & Sawang & $\begin{array}{l}\text {-P2TP2A } \\
\text { assistance in } \\
\text { the community } \\
\text {-Family legal } \\
\text { consultation } \\
\text { with P2TP2A }\end{array}$ & $\begin{array}{l}\text {-Disability } \\
\text {-Rape several } \\
\text { times ( } 6 \\
\text { months } \\
\text { pregnant) }\end{array}$ \\
\hline 18 & N.A bt, (19) & Foreigners & Muara Batu & $\begin{array}{l}\text {-P2TP2A } \\
\text { assistance in } \\
\text { the community } \\
\text {-Family legal } \\
\text { consultation } \\
\text { with P2TP2A }\end{array}$ & $\begin{array}{l}\text { Raped } \\
\text { repeatedly }\end{array}$ \\
\hline 19 & $\begin{array}{l}\text { Syf bt He, } \\
\text { (7) }\end{array}$ & Neighbors & Baktiya & $\begin{array}{l}\text {-P2TP2A } \\
\text { assistance in } \\
\text { the community } \\
\text {-Family, legal } \\
\text { consultation }\end{array}$ & $\begin{array}{l}\text { Sexual } \\
\text { harassment }\end{array}$ \\
\hline
\end{tabular}




\begin{tabular}{|l|l|l|l|l|l|}
\hline & & & $\begin{array}{l}\text { with P2TP2A } \\
- \text { Customs, } \\
\text { ending in } \\
\text { peace }\end{array}$ & \\
\hline 20 & M S, (14) & $\begin{array}{l}\text { OTK some } \\
\text { people }\end{array}$ & Samudra & $\begin{array}{l}\text {-P2TP2A } \\
\text { assistance in } \\
\text { the community } \\
\text {-Family; Legal } \\
\text { consultation } \\
\text { with P2TP2A }\end{array}$ & $\begin{array}{l}\text {-Disability } \\
\text {-Rape in } \\
\text { turns }\end{array}$ \\
\hline
\end{tabular}

From the many data above, the researchers then sought the validity of their handling up to the police and prosecutors. Based on the recapitulation data of the North Aceh Regional Police Unit for Protection of Women and Children (PPA) in 2016-2017, in 2016 there were 27 perpetrators of sexual violence and in 2017 there were 15 of these people in general who committed crimes of sexual harassment, escaping children underage women, molestation, child abuse, crimes against decency, promiscuity. ${ }^{28}$ the crime / criminal act has been processed as an effort to protect victims and sanctions that are repressive against the perpetrators, so that the perpetrators are ensnared by Law Number 35 of 2014 concerning Amendments to Law Number 23 of 2002 concerning Child Protection namely article 80 paragraph 1 everyone violates the provisions referred to in article 76C (everyone is prohibited from placing, allowing, involving, ordering to involve children in situations of mistreatment and neglect) shall be sentenced to a maximum imprisonment of 3 (three) years 6 (six months) and / or a maximum fine a lot of Rp. 72,000,000 (seventy-two million rupiah). and paragraph 4 reads "criminal plus a third of the provisions referred to in paragraph (1), paragraph (2), and paragraph (3) if the parent carries out the conduct. ${ }^{29}$

In addition to the above article the police based on the case, the perpetrators were also charged with Article 81 paragraph 1.2 and article 82 paragraph (1), article 81 paragraph (1) which reads "Any person who violates the provisions as referred to in article $76 \mathrm{D}$ is convicted with a maximum imprisonment short 5 (five) years and a maximum of 15 (fifteen) years and a maximum fine of Rp. 5,000,000,000 (five billion rupiah), paragraph (2). Criminal provisions referred to in paragraph (1) shall also apply to anyone who intentionally commits tricks, a series of lies, or persuades a child to have intercourse with him or others. Whereas in Article 82 paragraph (1) each person who carries out the provisions referred to in article $76 \mathrm{E}$ shall be sentenced to a maximum term of 5 years and a maximum of 15 years and a maximum fine of Rp.5,000,000,000 (five billion Rupiah).

The North Aceh District Prosecutor's Office in 2016 there were 13 people charged while in 2017 there were 16 people, the indictment article is article 82 of the Republic of Indonesia Law, Number 35 of 2014 concerning Child Protection, article 81 (2) jo (82 (1), article 81 (2) jo 82 (1), article 81 (1) (2) jo 82 (1), (2), of the total investigators' demands, the lowest criminal charge was a criminal body of 5 (five) years in prison while the highest charge was 15 (fifteen) years in prison, while the highest fine is 1 billion subsidiary 3 months imprisonment, while the lowest court sentence is 3 (three) years 6 (six months) with the highest criminal body 12 years in prison and a fine of 1 billion subside 2 months of

\footnotetext{
${ }^{28}$ Saiful ST, BRIBKA NRP 82061385, Kanit PPA data diambil tanggal 23 agustus 2019.

${ }^{29}$ Law Number 35 of 2014 concerning Amendments to Law Number 23 of 2002 concerning Child Protection
} 
imprisonment, the highest offender receiving a sentence is the suspect numbered 111 / Lsk / 06/2017, with the initials abd Ga bin Ba with prosecutors Andri kurnia Yusda SH and M. Heriyansyah SH, the indictment article subject to Article 81 (1) jo 82 (1) 1) RI Law No. 35 of 2014 concerning Child Protection. ${ }^{30}$

From the description above, it can be concluded that sexual violence against children in the district of North Aceh revolves around several forms, namely rape, sexual harassment, sodomy, incest, escaping underage girls, molestation and intimidation. In general, the perpetrators are adults with various modes. Some use force directly and also by persuading victims by being promised a reward of some money, buying something the victim wants. While the perpetrators vary, first offenders who have blood relations such as biological fathers, uncles, cousins, second: offenders who have kinship ie stepfathers, neighbors, third: offenders who have an educational relationship namely teachers and finally offenders who have intimate relationships namely boyfriends the woman herself. All actors are ensnared by Article 81 (1) jo 82 (1) RI Law. No. 35 of 2014 concerning child protection.

\subsection{Handling cases of sexual violence against children by P2TP2A}

The form of handling provided by the P2TP2A institution is in the form of assistance to the victim, which is a process of social relations between the companion and the victim in the form of providing facilities to solve problems starting from the communities where the victims are domiciled to keeping the victims safe. The person who is assisting here is a member of the board of P2TP2A North Aceh patent who has received legality from the government as an institution that has the functional and professional ability to assist victims who are referred to as clients. The initial step taken by the facilitator is to build an initial contact relationship with the victim to involve the victim, family and community in a situation of helping victims by communicating both verbally and nonverbally in introductions, conducting interviews, listening, using body language and so on. Then intervene by providing motivational guidance, spiritual guidance and so on.

After having the opportunity to provide assistance, P2TP2A facilitates the victim to gain access to various sources that can accelerate the successful handling of the case, namely legal consultation where P2TP2A will ask the victim and family whether the case was settled family based on local customary law or with state law in the police to the court, if the case of sexual violence is still in the category of minor criminal offenses does not cause physical and mental suffering and should be forgiven this can be resolved according to customary law resolved by local customary and religious leaders and if the case is included in a criminal offense resulting in casualties both physically and psychologically this will be taken applicable legal channels where the victim will be forwarded by medical referral services in the form of a post mortem to the victim to become evidence while in the police.

On the sidelines of the legal process P2TP2A motivates, encourages here the counselor needs to be careful in asking and advising not to get the victim hurt a second time, because the core of the guidance aims to overcome the various problems faced by the victim. If indeed the depression experienced by the victim is very severe, P2TP2A will work closely with the health department to hand over the victim to be fostered and mentored by a psychologist. Will also cooperate with the Ulema Consultative Assembly (MPU) commission $\mathrm{B}$ in the field of education for the strengthening of spirituality. Furthermore, based on the

\footnotetext{
${ }^{30}$ Yudi Permana, SH. MH, Junior prosecutor as head of the General Crimes Section (Kasi Pidum), data was taken at the North Aceh Lhoksukon District Attorney's Office on July 11, 2019.
} 
consent of the victim and the family of the case will be reported to the police (sector police), then proceed to the police chief to be investigated and investigated, every investigation is always accompanied to oversee the occurrence of emphases, where the victim is going through periods of traumatic and still in the pressures from the perpetrator that still silenced there was no courage to reveal what exactly had happened to him.

In order to deal with further acts of violence provided by P2TP2A are safe houses (shelter) considering that in the North Aceh police chief there are no safe houses so P2TP2A is partnering with salafi dayah (traditional Islamic boarding schools) in the northern Aceh district. This safe house service is given to victims who feel that their security and safety are disturbed. The existence of victims at home is safe and secure and their security is guaranteed and kept confidential. When the victim is in a stable condition, P2TP2A provides advocacy services or legal assistance to victims of physical violence until the legal turmoil, namely advocacy and prosecution, so that in the legal process, they always receive treatment based on the needs of the child, for example, the victim is placed in a child's room, maintaining the confidentiality of victims who are personal to other people. Show empathy attitude full of justice and sincerity if there is legal certainty then the next handling will be handled by the government (social service) in a comprehensive manner by keeping the victims as comfortable as possible. ${ }^{31}$

\section{Conclusion}

The handling of cases of sexual violence against children in North Aceh district is still not optimal, where the social service has not been able to deal with it comprehensively as well as the courts focusing on crimes for perpetrators rather than thinking about tackling sexual violence crimes and guaranteeing the restoration and fulfillment of restitution rights for victims. Children rarely get what is called deserving of legal protection and remediation. Children of victims of sexual violence should receive treatment for restitution and compensation as a result of a crime. The rights of victims and their remedies are still numbered compared to the perpetrators. So it can be said that the punishment of perpetrators of sexual crimes against children actually does not have any effect on the victims only to the extent of retaliation in the name of the interests of the victims. Need to get more attention on cases of sexual assault. While the fulfillment of victims' rights must be paid by the perpetrators and if the perpetrators are unable, then the state must be assisted in the form of compensation. In northern Aceh there is a Baitulmal institution that has very significant funds.

Damages given to victims or their families by perpetrators or third parties, can be in the form of return of property, payment of compensation for loss or suffering, or reimbursement of costs for certain actions, is a form of protection against human existence because humans have karamah rights (breeding rights ), and fadhilah rights (human priority). This is in accordance with the main mission of Islamic teachings rahmatan lil'alamin. The purpose of Islamic law is called the Maqashid Shari'ah (the basic purpose of Islamic law) which includes five things one of which is - Hifz al-nasl, namely the guarantee of safety for his descendants (his children. forbidden adultery and forbidden sexual harassment).

${ }^{31}$ Hasil wawancara dengan Ibu Eli ketu P2TP2A Kabupaten Aceh Utara 5 November 2019 


\section{References}

Abu Yahya Zakariyya al- Anshary, Fath al-Wahhab bi Syarh Manhaj al-Thullab, Beirut : Daar al-Fikr, n.d..

Al-Imam Muhyiddin al-Nawawi, (2007). al-Majmu' Syarh al-Muhazzab, Cet. 1, Juz IX, Beirut : Daar al-Kutub al-'Ilmiyah. Budapest International Research and Critics Institute (BIRCI-Journal), 170-180.

Abdullah, 2018. Role Optimization of Indigenous Institutions for Case of Violence

Against Women and Children,

(Analysis Study in Aceh and Padang Provinces)

Sayyid al- Bakri bin Sayyid Muhammad Syatha al-Dimyathi, I'anah al-Thalibin, Semarang: Toha Putra, t.th

Syekh Syihab al-Din Ahmad bin Ahmad bin Sallamah al-Qulyuby, Qulyubi, Juz IV, Semarang : Daar Ihya' al-Kutub al-'Arabiyah, n.d.

Syekh Ibrahim al-Bajuri, (2007). al- Bajuri, Juz II, Cet. 1, Beirut : Daar al-Kutub alIslamiyah.

Syihabuddin Ahmad bin Hajar al-Haitami, (2006) Tuhfah al-Muhtaj fi Syarh al-Minhaj, Software al-Maktabah al-Syamilah Idar Versi 3.15.

Zain al-Din al- Malibary,Fath al-Mu in, Juz II, Semarang : Toha Putra, n.d.

'Izuddin bin 'Abd al-Salām, (1980). Qawā'id al-Aḥkām fî̀ Maṣālih al-Anām, Juz I, Bairūt: Dār al-Jail,

Abdurrahman al-Maliki, (2002). Sistem Sanksi dalam Islam, Penerj. Syamsuddin Ramadlan, Judul asli: Niz̄ām al- 'uqūbāt, cet. I, Bogor: Pustaka Thariqul Izzah.

Abū al-Faḍal Jamaluddīn Muḥammad bin Makram bin al-Afriqī al-Mișri Ibn Manzhūr, Lisān al-'Arab, Bairūt: Dār al-Ṣādir, t.th

Abū Isḥāq Ibrāhīm Ibn Mūsā al-Syāțibī, al-Muwāfaqāt fi Ușūl al-Syarī'ah,Juz II,Bairūt: Dār al-Kutub al-'Ilmiyyah, t.th

Abū Isma‘īl al-Bukhārī, (1987). Șaḥịh al-Bukhārī, Jilid II, Bairūt: Dār Ibn Kathīr alYamamah.

Adami Chazawi, (2005). Hukum Pidana Materil dan Formil di Indonesia, cet. II, Malang: Bayumedia Publishing.

Al-Tirmuzī, (2002). Sunan at-Tirmuzī, (Bairūt: Dār al-Kutub al-'Ilmiyyah.

Asjmuni Rahman, (1976). Kaidah-kaidah Fiqih (Qawa'id al-Fiqhiyyah), Jakarta: Bulan Bintang,

Bambang Waluyo, (1990). Narapidana dan Proses Pemasyarakatan, (Jakarta: Sinar Grafika)

Bagong Suyanto, (2010) Masalah Sosial Anak, Jakarta: Kencana.

C. S. T. Kansil, at.al, (2009). Tindak Pidana Dalam Undang-undang Nasional, Jakarta: Jala Permata Aksara.

E. Utrecht, (1958). Hukum Pidana I, Jakarta: Universitas Jakarta.

Fathurrahman Djamil, (1997). Filsafat Hukum Islam Jilid II, Jakarta: Logos Wacana Ilmu,

Mahmul Siregar dan kawan-kawan, (2007). Melindungi Anak Dengan Hukum, Medan: Pusat Kajian dan Perlindungan Anak.

Muhammad Abū Zahrah, Al-Jarīmah wa al- 'Uqūbat fì al-Fīqh al-Islamī, Cairo: Maktabah alAngelo al-Mișriyyah, t.th

Muhammad bin Ahmad al-Khatib al-Syarbini, (2006). Mughni al-Muhtaj, Bag. XVIII, Software al-Maktabah al-SyÉmilah Î̃dar Versi 3.15. 
Nagaty Sanad, (1991). The Theory of Crime and criminal Responsibility in Islamic Law Sāria, Chicago: Office of Internashional Criminal Justice.

Nur Ahmad Fadhil Lubis, (2003). Yurisprudensi Emansipatif; Tela'ah Filsafat Hukum, cet. I, Bandung: Citapustaka Media. 